\title{
Impact of clam and mussel farming on benthic metabolism and nitrogen cycling, with emphasis on nitrate reduction pathways
}

\author{
Daniele Nizzoli ${ }^{1}$, David T. Welsh ${ }^{2, *}$, Elisa Anna Fano ${ }^{3}$, Pierluigi Viaroli ${ }^{1}$ \\ ${ }^{1}$ Dipartimento di Scienze Ambientali, Università degli Studi di Parma, Parco Area delle Scienze 33/A, 43100 Parma, Italy \\ ${ }^{2}$ School of Environmental and Applied Sciences, and Centre for Aquatic Processes and Pollution, Griffith University, Gold \\ Coast Campus, PMB 50 GC Mail Centre, Bundall 9726 Queensland, Australia \\ ${ }^{3}$ Dipartimento di Biologia, Università degli Studi di Ferrara, Via L. Borsari 46, 44100 Ferrara, Italy
}

\begin{abstract}
The influences of suspended mussel and infaunal clam cultivation on benthic metabolism and nutrient cycling were compared in Goro lagoon, Italy. Both aquaculture types stimulated benthic metabolism, with sediment oxygen demand (SOD), $\mathrm{CO}_{2}$ and ammonium effluxes of up to 14, 16 and $1.2 \mathrm{mmol} \mathrm{m}^{-2} \mathrm{~h}^{-1}$. However, whilst mussel farming preferentially stimulated anaerobic metabolism and sediment reduction, clam farming did not. The mussel ropes were also large oxygen sinks and ammonium sources, with oxygen consumption and ammonium production rates of 1.4 to 1.5 and 0.18 to 0.43 $\mathrm{mmol} \mathrm{kg} \mathrm{k}^{-1}$. Consequently, the overall impacts of mussel farming on oxygen and nutrient dynamics were much greater than those of clam farming. There were also differences in nitrate-reduction processes and the nitrate sources that fuelled them. In winter, at high water column nitrate concentrations, highest nitrate reduction rates $\left(\sim 320 \mu \mathrm{mol} \mathrm{m} \mathrm{m}^{-2} \mathrm{~h}^{-1}\right)$ occurred at the mussel farm. Nitrate reduction was driven predominantly by water column nitrate and $\sim 30 \%$ of nitrate reduced was recycled to ammonium via dissimilatory nitrate reduction to ammonium (DNRA). At the control and clam farm sites, nitrate reduction rates were lower $\left(\sim 180 \mu \mathrm{mol} \mathrm{m} \mathrm{m}^{-2} \mathrm{~h}^{-1}\right)$, nitrification supplied $\sim 30 \%$ of nitrate and denitrification was dominant. In summer under low nitrate conditions, nitrate reduction was highest $\left(\sim 130 \mu \mathrm{mol} \mathrm{m} \mathrm{m}^{-2} \mathrm{~h}^{-1}\right)$ at the mussel farm site, but this activity was completely dependent upon water column nitrate and $95 \%$ of nitrate was reduced via DNRA. In contrast, at the clam farm station, DNRA was unimportant and nitrification was the major nitrate source for denitrification. Consequently, whilst nitrate reduction processes eliminated fixed $\mathrm{N}$ from the clam farm sediments via coupled nitrificationdenitrification, the dominance of DNRA at the mussel farm site resulted in a net $\mathrm{N}$ input to the sediment compartment. These large differences in the impacts of clam and mussel farming can be explained by the fact that infaunal clams stimulate transfer of both organic matter and oxygen to the sediment, whereas suspended mussels enhance only organic matter inputs.
\end{abstract}

KEY WORDS: Aquaculture impacts · Tapes philippinarum · Mytilus galloprovincialis · Biodeposition • Nutrient cycles $\cdot$ Nitrification · Denitrification · Dissimilatory nitrate reduction to ammonium

\section{INTRODUCTION}

Cultivation of bivalves has undergone a rapid expansion over recent decades (Naylor et al. 2000). According to the Food and Agriculture Organization of the United States (FAO), mollusc farming represented $23.5 \%$ of total aquaculture production in 2002 , with an annual yield of 10.7 million t (FAO 2003). Aquaculture is a socially and economically important industry in Italy and total production was $210000 \mathrm{t}$ in 1997, of which two-thirds was accounted for by filter-feeding bivalves. This cultivation is composed almost exclusively of the mussel Mytilus galloprovincialis grown as suspended rope cultures and the introduced clam sp. 
Tapes philippinarum, which is cultivated in the sediment. Both types are carried out principally in shallow coastal areas, especially coastal lagoons, such as Venice lagoon and the lagoons of the Po River Delta and Adriatic coast. Due to their shallowness and low tidal exchange, these lagoons may be particularly sensitive to aquaculture impacts, as many of them already suffer from acute eutrophication problems (Sfriso et al. 1992, Vollenweider et al. 1992, Viaroli et al. 2001). Hence, a profound understanding of the impacts of bivalve cultivation on system metabolism and nutrient dynamics is a prerequisite for the sustainable management of these ecosystems.

The widespread nature of bivalve cultivation has stimulated scientific research on the assessment of the impacts of mollusc farming on sediment and water quality (Kaiser et al. 1998). In general, cultivation of bivalves is considered to have a low impact compared to fish and crustacean farming, since it does not require inputs of feed as shellfish production is dependent upon natural phytoplankton productivity (Naylor et al. 2000). However, dense populations of filter feeders greatly enhance rates of sedimentation (biodeposition) of particulate organic matter, which is actively removed from the water column and deposited to the sediment as faeces and pseudofaeces. This can result in organic matter loads to the sediments of 10's to 100's of $\mathrm{g} \mathrm{C} \mathrm{m}^{-2} \mathrm{~d}^{-1}$ (see Graf \& Rosenberg 1997). Consequently, the presence of aquaculture facilities can significantly modify system energy and material cycles. This may lead to localised 'hot spots' of eutrophication, as organic matter transported from adjacent marine or terrestrial areas is preferentially deposited within a restricted area via biodeposition. Several studies have shown that these high organic matter loads stimulate mineralisation rates, increasing sediment oxygen demand (SOD) and N release (Dahlback \& Gunnarsson 1981, Kaspar et al. 1985, Baudinet et al. 1990, Mazouni et al. 1996, Gilbert et al. 1997, Kaiser et al. 1998). For example in Beatrix Bay, New Zealand, Chistensen et al. (2003) measured a 2-fold increase in SOD beneath mussel long lines compared to a reference site, associated with a $\sim 14$-fold increase in ammonium efflux. Similarly, Kaspar et al. (1985) reported SODs of between 1.2 and $3.5 \mathrm{mmol} \mathrm{m}^{-2} \mathrm{~h}^{-1}$ and a 2 - to 4 -fold increase in $\mathrm{N}$ mineralisation rates in an area of Kenepuru Sound, New Zealand exploited for cultivation of mussels. Whereas, in shallower, warmer Mediterranean waters, Baudinet et al. (1990) reported that organic enrichment due to mussel culture increased sediment $\mathrm{N}$ release by up to 44 times compared to unimpacted areas, and sediments under Crassostrea gigas cultures in the Etang de Thau had an SOD of 1.8 to 3 and ammonium effluxes 1 - to 5 -fold higher than unfarmed control sites (Mazouni et al. 1996).
However, few studies have addressed the effects of bivalve farming on sediment $\mathrm{N}$ cycling and especially processes such as nitrification, denitrification and dissimilatory nitrate reduction to ammonium (DNRA), which influence $\mathrm{N}$ retention and loss dynamics. Additionally, these rare studies have only considered sediments below suspended culture systems and have determined denitrification and DNRA as potential rates in nitrate-enriched slurries (Kaspar et al. 1985, Gilbert et al. 1997, Bonin et al. 1998). In these cases, denitrification was determined by the acetylene inhibition technique. Unfortunately, acetylene is also a potent inhibitor of nitrification and therefore this method only measures denitrification based on pre-existing nitrate and not coupled nitrification-denitrification (Knowles 1990). Moreover, in the organic matter-enriched sediments below aquaculture facilities, the presence of sulphide may result in incomplete inhibition of denitrification by acetylene, leading to underestimation of rates (Christensen et al. 1989). Taking these drawbacks into account, only the study of Christensen et al. (2003), where denitrification was measured using the ${ }^{15} \mathrm{~N}$-isotope pairing technique can be considered to give truly reliable data. These authors reported that denitrification and especially coupled nitrification-denitrification rates were inhibited below the mussel ropes. However, it is difficult to draw general conclusions on the impacts of bivalve farming on denitrification from this single study, as other factors would also be expected to influence the effects of biodeposition on nitrification and denitrification. For example, all the above cited studies have focussed on suspended mussel cultures which influence sediment denitrification rates only through biodeposition, but no studies have addressed the cultivation of infaunal species where the animals, as well as increasing organic matter inputs, also influence fluxes of oxygen and nitrate (substrates for nitrification and denitrification) to the sediment through bioturbation and bioirrigation (Pelegrí \& Blackburn 1995, Welsh 2003). Finally, no studies of bivalve farming have addressed its influence on DNRA, which competes with denitrification for nitrate, even though the high organic matter inputs to farmed sediments would be expected to favour DNRA (Tiedje 1988).

In this study we determined the effects of suspended mussel and infaunal clam cultivation on SOD, carbon oxidation rates, sediment-water column $\mathrm{N}$-fluxes, denitrification and DNRA under summer and winter conditions, in the Sacca di Goro, Italy, which is exploited for both types of aquaculture. These data are compared with a control station in order to evaluate the effects of the different cultivation systems. In addition, the role of the mussel ropes as a sink for oxygen, source/sink for inorganic $\mathrm{N}$, and a site for denitrification and DNRA at the mussel farm were also assessed. 


\section{MATERIALS AND METHODS}

Study site. The Sacca di Goro $\left(44^{\circ} 82^{\prime} \mathrm{N}, 12^{\circ} 27^{\prime} \mathrm{E}\right)$ is a small lagoon of the Po River Delta, Italy, with a surface area of $26 \mathrm{~km}^{2}$ and mean depth of $1.5 \mathrm{~m}$. Presently, $\sim 8 \mathrm{~km}^{2}$ of the lagoon is licensed for farming of the clam Tapes philippinarum. Within this area, zones are seeded throughout the year at recommended densities of 100 to 500 ind. $\mathrm{m}^{-2}$ but local densities can be $>2000$ ind. $\mathrm{m}^{-2}$. At maturity, clam biomass is typically 1 to $5 \mathrm{~kg} \mathrm{~m}^{-2}$, but can be $>15 \mathrm{~kg} \mathrm{~m}^{-2}$ in intensively farmed locations, and production is $\sim 10000 \mathrm{t} \mathrm{yr}^{-1}$ (Bartoli et al. 2001, Castaldelli et al. 2003, Viaroli et al. 2003). In contrast to the diffuse clam farms, mussel farming is localised in the central part of the lagoon (Fig. 1). The farmed area is constituted by 5 parallel lines of $\sim 1 \mathrm{~km}$ long trellis, spaced at $\sim 50 \mathrm{~m}$ intervals. Biomass is high compared to the clam fields and can attain $60 \mathrm{~kg} \mathrm{~m}^{-2}$ at maturity. Production was maximally $2000 \mathrm{t} \mathrm{yr}^{-1}$, but part of this activity was recently moved outside of the lagoon because of mussel deaths due to high summer water temperatures and episodic anoxia, and production in the lagoon has declined to below $1000 \mathrm{t} \mathrm{yr}^{-1}$.

Within the lagoon, we defined 3 sampling stations (Fig. 1): Stn M located directly below the mussel ropes, Stn V in an intensively cultivated area within the clam fields and Stn C (a control station) in a non-cultivated area equidistant between the other 2 sites.

Sample collection and maintenance. Sediment cores were collected in February and July 2002 using $30 \mathrm{~cm}$ long transparent Plexiglas core tubes with an $8 \mathrm{~cm}$ (flux and nitrate reduction rate determinations) or $5 \mathrm{~cm}$ internal diameter (sediment characteristics). At each

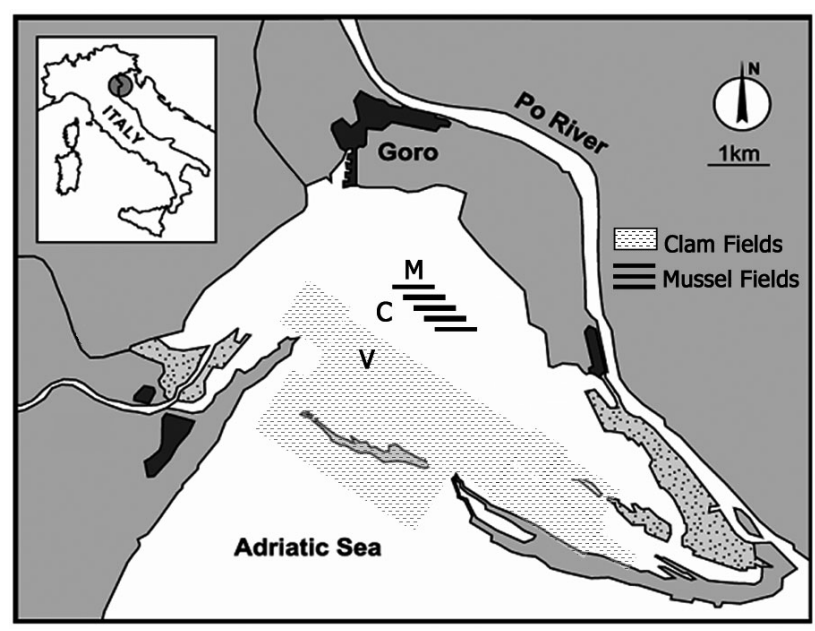

Fig. 1. The Sacca di Goro lagoon indicating the extent of the areas licensed for clam (Tapes philippinarum) and mussel (Mytilus galloprovincialis) farming, and the locations of sampling stations $\mathrm{C}$ (control site), V (clam farm site) and M (mussel farm site) site, water samples were collected for inorganic $\mathrm{N}$ and salinity determinations and $75 \mathrm{l}$ of water was collected for core maintenance and incubation. In addition, 3 mussel ropes were collected from the mussel farm site. All samples were returned to the laboratory within $1 \mathrm{~h}$, and sediment cores were transferred to separate aerated tanks and maintained at in situ temperature in the dark, in water collected from the same site. In cores for flux and nitrate reduction rate determinations, mixing of the water within the cores was assured by suspended magnets fitted inside the cores and driven by a central electric motor (Welsh et al. 2001). Cores were maintained overnight prior to the initiation of experiments.

Sediment characterisation. Each of 5 cores were cut into 4 sections $(0-1,1-2,2-5,5-10 \mathrm{~cm})$ and the slices rapidly homogenised. Sub-samples of $5 \mathrm{~cm}^{3}$ of the homogenate were collected using cut-off $10 \mathrm{ml}$ syringes, transferred to pre-weighed aluminium dishes and weighed to determine sediment density. Sediment porosity $\left(\mathrm{ml} \mathrm{H}_{2} \mathrm{O} \mathrm{ml} \mathrm{sed}{ }^{-1}\right)$ was determined as loss of wet weight after $24 \mathrm{~h}$ at $70^{\circ} \mathrm{C}$, organic matter content as loss of dry weight after combustion at $550^{\circ} \mathrm{C}$ for $3 \mathrm{~h}$. Dried sediments from each depth horizon of the individual cores were pooled and mixed, and sub-samples were taken and analysed for organic carbon and nitrogen contents using a Carlo Erba CN analyser.

Sediment-water column flux, denitrification and DNRA rate determinations. Oxygen, $\mathrm{CO}_{2}$ and dissolved inorganic nitrogen (DIN) fluxes were determined during dark incubation. The water in the incubation tanks was replaced with fresh water from the same site, and the water within each core exchanged with the tank water by repeatedly withdrawing water from within the core using a $100 \mathrm{ml}$ syringe. To initiate incubations, the water level in the tank was lowered to below that of the core tops, samples for oxygen, $\mathrm{CO}_{2}$ and DIN determinations were collected, and the cores were sealed with floating Plexiglas lids. Cores were incubated in the dark for between $30 \mathrm{~min}$ and $3 \mathrm{~h}$ depending on the season and sampling site. At the end of the incubation, the floating lids were removed and water samples collected for oxygen, inorganic carbon and DIN determinations. Flux rates were calculated from the change in water column concentration of the solutes as described by Welsh et al. (2000).

After flux measurements, cores were left uncapped and submerged for $2 \mathrm{~h}$ before determination of denitrification and DNRA rates. Prior to the incubations, the water in the tanks and cores was replaced with water from the same site as described above. The water in the tanks was lowered to below the core tops and samples were collected for determination of ambient nitrate concentration. Sufficient of a stock 99.9 atom \% ${ }^{15} \mathrm{~N}$-nitrate solution was added to give a concentration 
of $\sim 30 \mu \mathrm{M}$, the water was mixed and a sample was collected for determination of nitrate concentration to allow calculation of the actual ${ }^{15} \mathrm{~N}$ addition. The cores were closed using floating Plexiglas lids and incubated for $30 \mathrm{~min}$ to $3 \mathrm{~h}$, with the actual time determined from the measured oxygen fluxes, such that the water column oxygen remained above $80 \%$ of the initial value, as is required for accurate use of the isotope pairing technique (Nielsen 1992).

At the end of the incubation, a sub-core of $2 \mathrm{~cm}$ internal diameter was inserted into each core and $5 \mathrm{ml} 7 \mathrm{M}$ $\mathrm{ZnCl}_{2}$ was added to the water outside the sub-core to inhibit denitrification. The sub-core was removed and the contents transferred to a $500 \mathrm{ml}$ plastic bottle containing sufficient powdered $\mathrm{KCl}$ to give a final concentration of $\sim 2 \mathrm{M}$. Bottles were shaken for $1 \mathrm{~h}$ to extract the exchangeable ammonium pool and sub-samples were collected, filtered and frozen for determination of ammonium concentration and the ${ }^{15} \mathrm{~N}$-enrichment of the ammonium pool. The remaining sediment in the cores was slurried and sub-samples were fixed for analysis of the isotopic composition of the dissolved $\mathrm{N}_{2}$ pool as previously described (Welsh et al. 2001). Denitrification rates were determined according to the isotope pairing method (Nielsen 1992), as described (Welsh et al. 2000). Rates of DNRA based on water column nitrate $\left(\mathrm{DNRA}_{\mathrm{W}}\right)$ were calculated from the ${ }^{15} \mathrm{~N}$ enrichment of the water column nitrate and sediment-exchangeable ammonium pools according to Risgaard-Petersen \& Rysgaard (1995). Rates of DNRA coupled to sediment nitrification $\left(\mathrm{DNRA}_{\mathrm{N}}\right)$ were estimated from DNRA ${ }_{W}$ and the ratio between $D_{N}$ and $D_{W}$, assuming that both nitrate reduction processes occurred in similar sediment zones (Risgaard-Petersen \& Rysgaard 1995).

At the end of the incubations, the sediment in each core and the corresponding sediment extracted for ammonium were pooled and sieved through a $500 \mu \mathrm{m}$ net in order to determine the density and biomass of clams and other macrobenthic species.

Determination of oxygen and inorganic nitrogen fluxes of the mussel rope community. On both sampling dates, 3 intact mussel ropes were hand collected. At the laboratory, each rope was submerged in a PVC tube ( $25 \mathrm{~cm}$ internal diameter $\times 2 \mathrm{~m}$ length), which was continually flushed with lagoon water at a rate of $500 \mathrm{l}$ $\mathrm{h}^{-1}$ in order to maintain a constant supply of particulate matter for the mussels and their epiphytes. The water within each tube was mixed using 2 submerged water pumps positioned at the top and bottom of the tube (Fig. 2). Oxygen consumption and DIN fluxes due to the mussel rope community were determined during dark incubations. The water supply to the tubes was interrupted and each tube sealed with a floating polystyrene cap. Incubations lasted approximately $1 \mathrm{~h}$ and

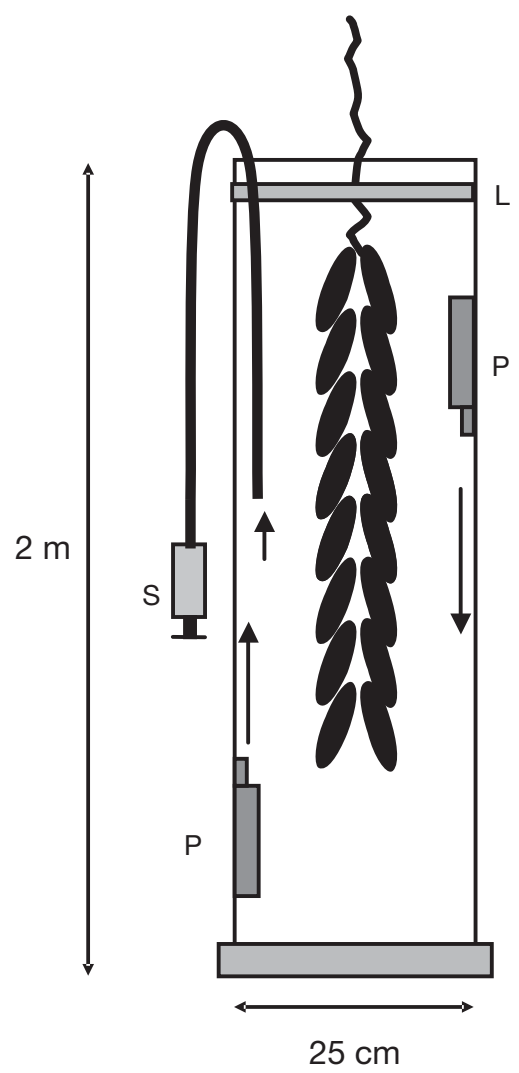

Fig. 2. Schematic representation of the incubation system used for the determination of oxygen and inorganic nitrogen fluxes across the mussel ropes. The scheme shows the system set-up during incubations, when the external water supply was removed and the tube top was sealed with a floating polystyrene lid (L). Water mixing was assured by 2 small inline pumps (P) and samples were collected via a sampling tube connected to a $100 \mathrm{ml}$ syringe (S)

water samples were collected for oxygen and DIN determinations at 10 min intervals via a sampling tube located within the incubation tubes (Fig. 2). At the end of the incubations, the mussel ropes were removed and weighed.

Flux rates across the mussel ropes were calculated from the best-fit linear regression of the solute concentrations with time. Specific fluxes per kilogram of mussel rope were calculated by taking into account the total weight of the mussel ropes incubated, and areal rates were calculated using the mean rope biomass and the normal stocking density in the Sacca di Goro of 5 ropes $\mathrm{m}^{-2}$.

Determination of denitrification and DNRA associated with the mussel ropes. Denitrification and DNRA rates were determined during incubations of preweighed sub-samples ( 1 kg fresh weight) of mussel rope incubated in sealed 121 PVC tubes following an addition of $\sim 30 \mu \mathrm{M}{ }^{15} \mathrm{~N}$-nitrate. An aquarium pump within the tubes ensured homogenous mixing of the 
water during the 30 min incubations. Water samples for nitrate concentration were collected prior to and after the ${ }^{15} \mathrm{~N}$-nitrate additions to allow calculation of the actual ${ }^{15} \mathrm{~N}$ enrichment of the nitrate pool. At the end of the incubations, water samples were collected for determination of ammonium concentration, the ${ }^{15} \mathrm{~N}$ enrichment of the dissolved ammonium pool and the isotopic composition of the dissolved $\mathrm{N}_{2}$ pool. Denitrification and DNRA rates were determined from the isotopic composition of the dissolved $\mathrm{N}_{2}$ and ammonium pools as previously described (Risgaard-Petersen \& Rysgaard 1995).

Analytical methods. Dissolved oxygen was determined by the Winkler method (American Public Health Association, APHA 1975) and total carbonate concentrations for determination of $\mathrm{CO}_{2}$ fluxes by titration with $0.1 \mathrm{M} \mathrm{HCl}$, as described by Anderson et al. (1986). Ammonium concentrations were determined by the indophenol blue method described by Bower \& Holm Hansen (1980). Nitrate was determined by diazotation, after reduction to nitrite over cadmium columns (APHA 1975). The abundance of ${ }^{14} \mathrm{~N}^{15} \mathrm{~N}$ and ${ }^{15} \mathrm{~N}^{15} \mathrm{~N}$ in the dissolved $\mathrm{N}_{2}$ pool was determined by mass spectrometry at the National Environmental Research Agency, Silkeborg, Denmark, as previously described by Risgaard-Petersen \& Rysgaard (1995). The ${ }^{15} \mathrm{~N}$ enrichment of ammonium pools was determined by the same method following micro-diffusion and hypobromite oxidation of the ammonium to $\mathrm{N}_{2}$ (Nielsen 1992, Risgaard-Petersen et al. 1995).

Statistical methods. Normality of data was assumed, and homoscedasticity was confirmed using the Cochran test. Data were analysed by 1-way ANOVA, with an a posteriori comparison of the means performed using the t-method (Sokal \& Rohlf 1995).

\section{RESULTS}

\section{In situ water column characteristics and biomasses of the cultivated species}

All the investigated stations were located in the central part of the lagoon in an area influenced by tidal currents (Fig. 1). Water temperatures were 8 and $27^{\circ} \mathrm{C}$, and salinity between 20 and $25 \%$ in February and July respectively, at all 3 stations. DIN concentrations were highest during winter ( 75 to $110 \mu \mathrm{M}$ ) and decreased markedly to below $20 \mu \mathrm{M}$ at all 3 stations in summer (Table 1). Winter DIN pools were dominated by the nitrate ion which represented more than $95 \%$ of total DIN, whereas in summer, ammonium was the most abundant form of inorganic nitrogen accounting for 65 to $90 \%$ of total DIN in the water column. In general, DIN concentrations were very similar at Stns C and V, but concentrations were approximately $30 \%$ higher in winter and $50 \%$ lower in summer at Stn M (Table 1)

At Stn $\mathrm{M}$, there was a high mussel biomass in winter (Table 2), but due to a prolonged period of unseasonably high temperatures and calm conditions during May and June, most mussels were harvested to avoid excess mortality. The few remaining mussel ropes were small, as most of the mussels had died and detached, and only a few living animals and attached empty shells were present. The biomass of mussels in summer was therefore only $10 \%$ of the winter value (Table 2). The sediments below the mussel ropes were almost devoid of infauna in both seasons due to the highly reduced conditions (D. T. Welsh unpubl. data). At the clam farm site, the benthic community was dominated by the cultivated organisms, which were present at densities of between 1000 and 3000 ind. $\mathrm{m}^{-2}$. This was equivalent to biomasses of 11.7 and $6.6 \mathrm{~kg}$ fresh weight $\mathrm{m}^{-2}$ in February and July, respectively, due to the harvesting of the largest size classes between the 2 sampling dates. Some small polychaetes and crustaceans were also present in the farmed sediment, but their biomasses were insignificant compared to that of the clams (data not shown).

At the control station in winter, the benthic community consisted of low densities of Nereis succinea, other small polychaetes and small crustaceans, such as Corophium spp. and Gammerus spp. (data not shown).

Table 1. Water column ammonium, nitrite, nitrate and DIN concentrations at the mussel farm (M), clam farm (V) and control (C) stations in February and July 2002

\begin{tabular}{|lcccc|}
\hline Stn & $\mathrm{NH}_{4}{ }^{+}(\mu \mathrm{M})$ & $\mathrm{NO}_{2}{ }^{-}(\mu \mathrm{M})$ & $\mathrm{NO}_{3}{ }^{-}(\mu \mathrm{M})$ & $\mathrm{DIN}(\mu \mathrm{M})$ \\
\hline February & & & & \\
M & 1.7 & 2.6 & 107.1 & 111.4 \\
C & 0.9 & 2.0 & 72.6 & 75.5 \\
V & 0.9 & 2.0 & 72.6 & 75.5 \\
July & & & & \\
M & 5.2 & 1.3 & 1.0 & 7.5 \\
C & 14.0 & 0.6 & 1.0 & 15.6 \\
V & 14.0 & 0.6 & 1.0 & 15.6 \\
\hline
\end{tabular}

Table 2. Tapes philippinarum and Mytilus galloprovincialis. Biomass ( $\mathrm{kg} \mathrm{m}^{-2}$ fresh weight) at 3 sampling stations, during February and July 2002. Mussel biomass was calculated from the weight of 3 incubated mussel ropes assuming a normal stocking density of 5 ropes $\mathrm{m}^{-2}$

\begin{tabular}{|lccccc|}
\hline \multirow{2}{*}{ Stn } & \multicolumn{2}{c}{ February } & & \multicolumn{2}{c|}{ July } \\
\cline { 2 - 3 } & Clam & Mussel & & Clam & Mussel \\
\hline M & 0 & $34.9 \pm 11.6$ & & 0 & $\sim 3.0$ \\
$\mathrm{C}$ & 0 & 0 & & $0.8 \pm 0.5$ & 0 \\
$\mathrm{~V}$ & $11.7 \pm 2.9$ & 0 & & $6.6 \pm 0.9$ & 0 \\
\hline
\end{tabular}


However, in July, small individuals of Tapes philippinarum were also present at this site, at densities of between 200 and 600 ind. $\mathrm{m}^{-2}$, equivalent to $0.8 \mathrm{~kg}$ fresh weight $\mathrm{m}^{-2}$, presumably due to natural recruitment or drift of seed from the nearby cultivated areas.

\section{Sediment characteristics}

Sediments at Stns C and V were composed of medium to fine sands with low silt contents, mixed with some shell fragments. Both sediments were well oxidised in winter and summer, and had relatively low water contents (Table 3). Total organic matter, and organic carbon and nitrogen concentration in the upper $10 \mathrm{~cm}$ of sediment were relatively low and decreased with depth, but the concentrations and profiles were similar in both winter and summer (Table 3).

In contrast to the other 2 sites, the sediments at Stn $\mathrm{M}$, directly below the mussel ropes were composed mostly of fine textured muds and silts (mussel biodeposits) trapped within a matrix of whole and broken mussel shells. The sediment was highly reduced even in winter, appearing dark black except for a 1 to $2 \mathrm{~mm}$ layer of yellowish oxidised sediment at the sedimentwater interface, whereas in summer even this surface sediment layer was black and reduced. The sediment had a very high water content, and concentrations of total organic matter, and organic carbon and nitrogen were between 5 and 10 times higher than those at Stns $\mathrm{C}$ and V. Concentration profiles were relatively homogenous and changed little with depth (Table 3).

\section{Sediment-water column oxygen, and inorganic carbon and nitrogen fluxes}

At all the investigated stations, oxygen consumption rates were higher in July than in February $(p<0.01)$.
On both sampling dates, the highest SOD was measured at Stn V $\left(6.3 \pm 1.0\right.$ and $\left.14.1 \pm 3.2 \mathrm{mmol} \mathrm{m}^{-2} \mathrm{~h}^{-1}\right)$. These rates were $\sim 3$ times higher than those at Stns C and M (Fig. 3). Similarly, total carbon oxidation rates (measured as dissolved inorganic $\mathrm{C}$ fluxes) were highest at Stn V, with the values of 15.7 and $9.1 \mathrm{mmol} \mathrm{m}^{-2}$ $\mathrm{h}^{-1}$ measured in July and February respectively, being approximately 2 and 3 to 6 times higher than those at Stns $M$ and C, respectively (Fig. 3).

The SOD at Stns $C$ and $M$ were similar on both sampling dates, approximately 1.5 and $4.8 \mathrm{mmol} \mathrm{m}^{-2} \mathrm{~h}^{-1}$ in winter and summer, respectively. In contrast, carbon oxidation rates were 2 -fold higher at $\mathrm{Stn} \mathrm{M}$ in winter (Fig. 3), indicating a dominance of anaerobic metabolism at this station. Unfortunately, it is difficult to interpret the July data for these stations, due to the presence of small clams at Stn C, whose metabolism would have increased both oxygen uptake and inorganic carbon production rates, and the removal or death of most of the mussels at Stn M, which would have drastically

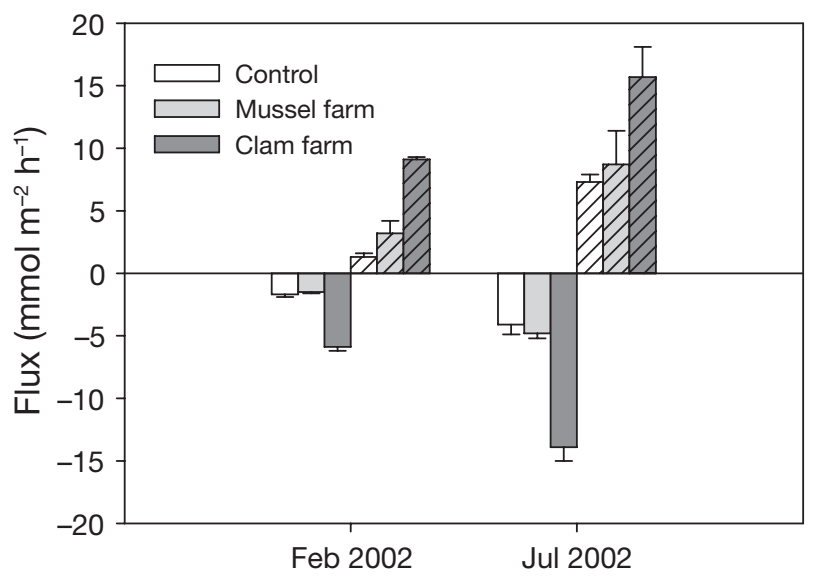

Fig. 3. Sediment-water column oxygen and $\mathrm{CO}_{2}$ (hatched bars) fluxes determined in dark incubated cores from the 3 sampling stations in February and July 2002. Consumption rates measured at the control, mussel, and clam stations. Error bars: + SE $(\mathrm{n}=5)$

Table 3. Porosity, organic matter (\% dry weight, DW), and organic carbon (C-org) and nitrogen (N-org) in the sediments of the mussel farm (M), clam farm (V) and control (C) stations in February and July 2002

\begin{tabular}{|c|c|c|c|c|c|c|c|c|c|c|c|c|c|}
\hline \multirow[t]{2}{*}{ Date } & \multirow[t]{2}{*}{$\begin{array}{l}\text { Sediment } \\
\text { layer }(\mathrm{cm})\end{array}$} & \multirow{2}{*}{\multicolumn{2}{|c|}{$\begin{array}{c}\text { Porosity } \\
\left(\mathrm{ml} \mathrm{ml}^{-1}\right) \\
\mathrm{C}\end{array}$}} & \multirow{2}{*}{$\overline{\mathrm{V}}$} & \multicolumn{3}{|c|}{$\begin{array}{c}\text { Organic matter } \\
(\% \mathrm{DW})\end{array}$} & \multicolumn{3}{|c|}{$\begin{array}{c}\text { C-org } \\
-\left(\mathrm{mg} \mathrm{g} \mathrm{DW}^{-1}\right)-\end{array}$} & \multicolumn{3}{|c|}{$\begin{array}{c}\mathrm{N} \text {-org } \\
-\left(\mathrm{mg} \mathrm{g} \mathrm{DW}^{-1}\right)-\end{array}$} \\
\hline & & & & & $\mathrm{M}$ & $\mathrm{C}$ & V & $\mathrm{M}$ & $\mathrm{C}$ & V & $M$ & C & V \\
\hline \multirow[t]{4}{*}{ February } & $0-1$ & 0.86 & 0.57 & 0.44 & 8.3 & 2.2 & 1.0 & 2.15 & 0.28 & 0.18 & 0.27 & 0.04 & 0.01 \\
\hline & $1-2$ & 0.86 & 0.46 & 0.43 & 8.4 & 1.8 & 1.2 & 2.11 & 0.27 & 0.19 & 0.29 & 0.05 & 0.02 \\
\hline & $2-5$ & 0.87 & 0.43 & 0.41 & 8.4 & 1.6 & 1.1 & 2.08 & 0.25 & 0.16 & 0.23 & 0.05 & 0.02 \\
\hline & $5-10$ & 0.87 & 0.47 & 0.41 & 7.9 & 1.4 & 1.3 & 2.02 & 0.16 & 0.24 & 0.25 & 0.02 & 0.02 \\
\hline \multirow[t]{4}{*}{ July } & $0-1$ & 0.86 & 0.42 & 0.44 & 12.2 & 3.0 & 3.1 & 1.87 & 0.33 & 0.34 & 0.30 & 0.05 & 0.03 \\
\hline & $1-2$ & 0.86 & 0.42 & 0.41 & 12.4 & 2.9 & 2.5 & 1.85 & 0.26 & 0.32 & 0.26 & 0.03 & 0.03 \\
\hline & $2-5$ & 0.86 & 0.4 & 0.39 & 12.7 & 2.7 & 2.8 & 2.45 & 0.19 & 0.22 & 0.25 & 0.02 & 0.02 \\
\hline & $5-10$ & 0.88 & 0.43 & 0.41 & 12.8 & 2.5 & 2.3 & 1.85 & 0.39 & 0.31 & 0.24 & 0.02 & 0.02 \\
\hline
\end{tabular}


reduced biodeposition of organic matter to the underlying sediment.

Ammonium was consistently regenerated from the sediment to the water column at all 3 stations in both seasons (Fig. 4). Ammonium effluxes were very high (0.8 to $1.2 \mathrm{mmol} \mathrm{m}^{-2} \mathrm{~h}^{-1}$ ) at both the bivalve farm stations and significantly different $(p<0.05)$ from those at the control station in both winter and summer. At Stn $\mathrm{C}$, there was a relatively low ammonium efflux of 0.12 $\pm 0.04 \mathrm{mmol} \mathrm{m}^{-2} \mathrm{~h}^{-1}$ in February. However, in July when populations of juvenile clams colonised the site, ammonium efflux increased to $0.64 \pm 0.08 \mathrm{mmol} \mathrm{m}^{-2}$ $\mathrm{h}^{-1}$ (Fig. 4).

Nitrate fluxes during winter, when the water column nitrate concentration was high (Table 1), were directed towards the sediment compartment at all of the stations (Fig. 4). The highest nitrate uptake rates, -465 and $-422 \mu \mathrm{mol} \mathrm{m}{ }^{-2} \mathrm{~h}^{-1}$, were measured at Stns $\mathrm{M}$ and $\mathrm{C}$, respectively, whereas nitrate uptake was significantly lower at Stn V $\left(-141 \mu \mathrm{mol} \mathrm{m}{ }^{-2} \mathrm{~h}^{-1} ; \mathrm{p}<0.01\right)$. During the summer, the only significant nitrate flux to the sediment was at Stn $\mathrm{M}\left(-184 \mu \mathrm{mol} \mathrm{m} \mathrm{m}^{-2} \mathrm{~h}^{-1}\right)$, whilst at Stns $C$ and $V$, nitrate fluxes were negligible and variable between replicate cores, with mean values indicating low nitrate effluxes of 2 and $8 \mu \mathrm{mol} \mathrm{m} \mathrm{m}^{-2} \mathrm{~h}^{-1}$

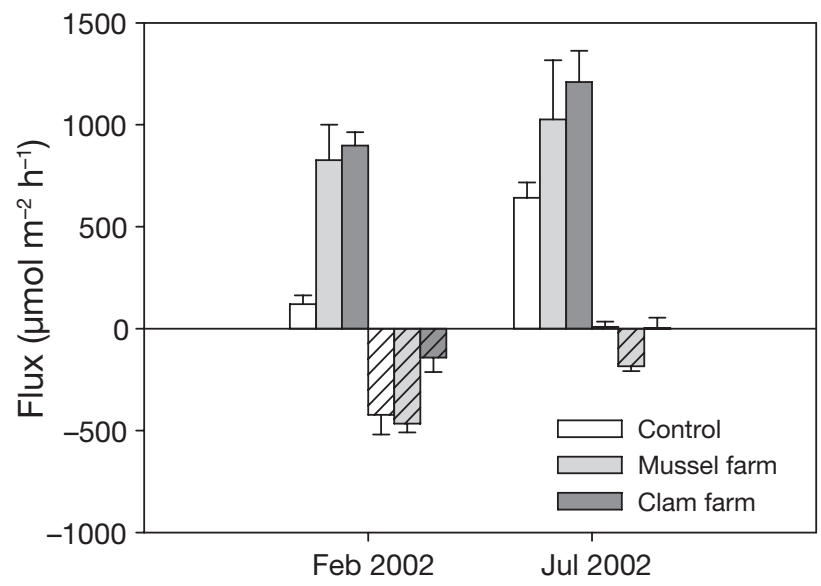

Fig. 4. Sediment-water column fluxes of ammonium and nitrate (hatched bars) measured during dark incubations of cores from the 3 sampling stations in February and July 2002. Error bars: + SE $(n=5)$ respectively. Nitrite fluxes (data not shown) were low $\left(-13\right.$ to $13 \mu \mathrm{mol} \mathrm{m}{ }^{-2} \mathrm{~h}^{-1}$ ) and highly variable at all 3 stations during both seasons.

\section{Oxygen and inorganic nitrogen fluxes across mussel ropes}

The mussel rope community was primarily comprised of the cultivated species, epiphytic species attached to the mussel shells, such as barnacles, oysters and the introduced mussel species Musculista senhousia, and crabs, polychaetes and small crustaceans, such as Gammarus spp., which colonised spaces within the mussel ropes. The surface of the ropes was covered by a layer of detritus, composed of deposited sediment and mussel faeces. This community had a major influence on oxygen consumption and nitrogen regeneration (Table 4). Oxygen consumption rates were similar in both winter and summer $\left(\sim 1.5 \mathrm{mmol} \mathrm{kg}^{-1} \mathrm{~h}^{-1}\right)$, but due to the higher biomass of the mussel ropes in winter (Table 2), the areal oxygen consumption of $-53.8 \mathrm{mmol}$ $\mathrm{m}^{-2} \mathrm{~h}^{-1}$ was 13 -fold higher than that in July. Inorganic nitrogen fluxes were dominated by the ammonium production of the mussel ropes, with specific ammonium production rates of 177 and $426 \mu \mathrm{mol} \mathrm{kg}^{-1} \mathrm{~h}^{-1}$ recorded in February and July, respectively. However, despite the higher specific rate of ammonium production in summer, the overall ammonium production in winter was 5 -fold higher than that in summer $(6.2 \mathrm{com}-$ pared to $1.2 \mathrm{mmol} \mathrm{m}^{-2} \mathrm{~h}^{-1}$ ), due to the much greater biomass of the mussel ropes (Table 2). Nitrate was consumed by the mussel rope community in both February and July, with the highest rate of $40.4 \pm 3.8 \mu \mathrm{mol} \mathrm{\textrm {kg } ^ { - 1 }}$ $\mathrm{h}^{-1}$ recorded in July, despite the 100-fold lower water column nitrate concentration during this period compared to February (Table 1).

\section{Rates of denitrification and DNRA}

Total denitrification $\left(D_{N}+D_{W}\right)$ rates were significantly higher $(p<0.01)$ in winter compared to summer at all the investigated stations (Fig. 5A). Winter values

Table 4. Oxygen $\left(\mathrm{mmol} \mathrm{kg} \mathrm{kh}^{-1}\right)$, ammonium and nitrate fluxes ( $\left.\mu \mathrm{mol} \mathrm{N} \mathrm{kg}{ }^{-1} \mathrm{~h}^{-1}\right)$ across the mussel ropes determined during dark incubations of whole mussel ropes, and rates of total denitrification $\left(D_{t}\right)$, denitrification of water column nitrate $\left(D_{W}\right)$ and coupled nitrification-denitrification $\left(\mathrm{D}_{\mathrm{N}}\right)$ determined during dark incubations of sub-samples of the mussel ropes, in February and July 2002. For ease of comparison, rates have been standardised per kilogram of mussel rope fresh weight to eliminate the effect of the difference in rope biomasses between the 2 periods. Data are presented as mean $\pm \operatorname{SE}(n=3)$

\begin{tabular}{|c|c|c|c|c|c|c|}
\hline Date & Oxygen & Ammonium & Nitrate & $\mathrm{D}_{\mathrm{t}}$ & $\mathrm{D}_{\mathrm{W}}$ & $\mathrm{D}_{\mathrm{N}}$ \\
\hline February & $-1.5 \pm 0.2$ & $176.7 \pm 37.1$ & $-16.9 \pm 45.7$ & $5.5 \pm 1.5$ & $5.1 \pm 1.3$ & $0.3 \pm 0.2$ \\
\hline July & $-1.4 \pm 0.1$ & $425.5 \pm 22.9$ & $-40.4 \pm 3.8$ & $10.3 \pm 1.1$ & $7.7 \pm 0.6$ & $2.6 \pm 0.6$ \\
\hline
\end{tabular}




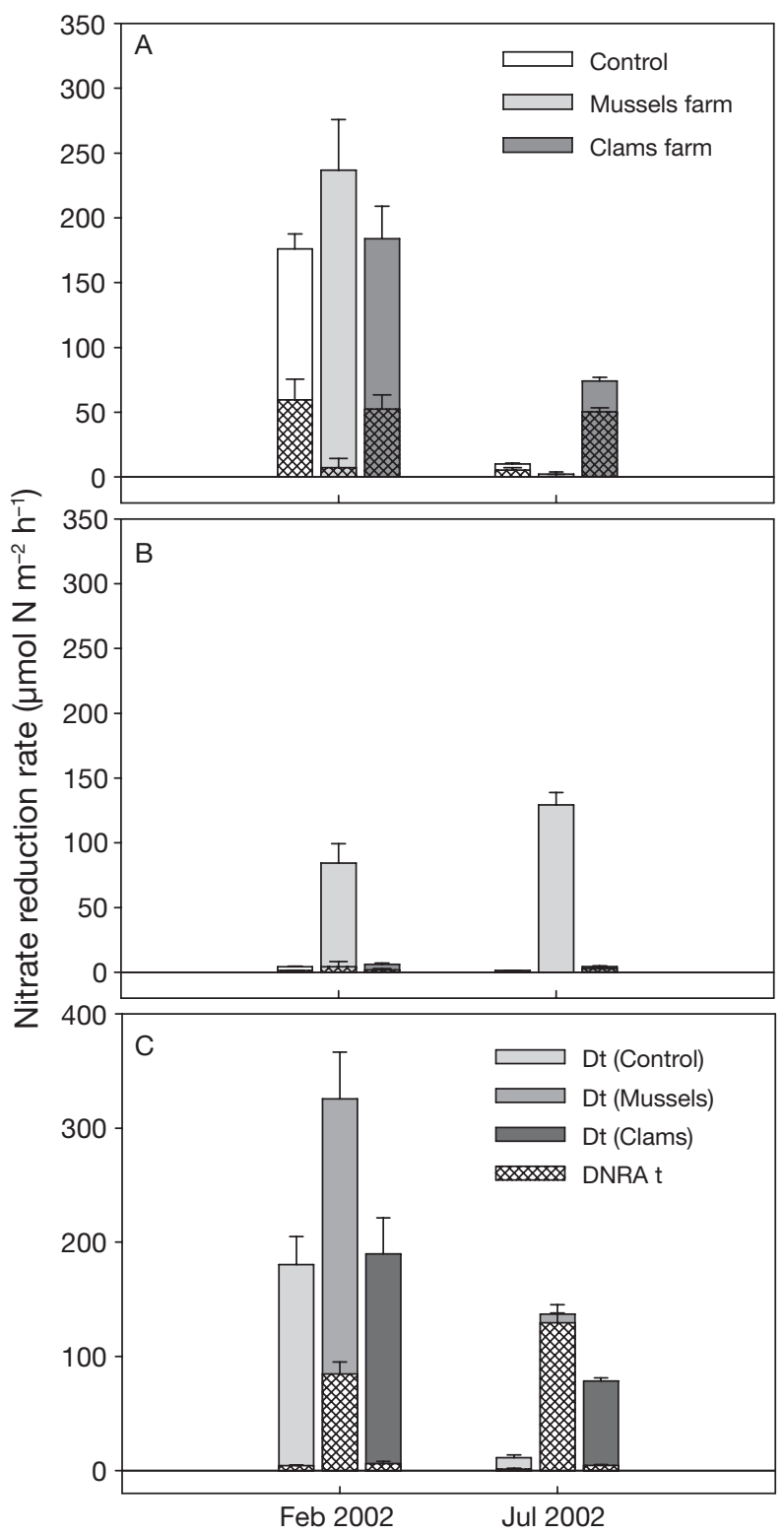

Fig. 5. Nitrate reduction processes during dark incubations of sediment cores from the 3 sampling stations in February and July 2002. Error bars: + SE $(n=5)$. (A) Denitrification rates, the cross hatched area of the bar indicates coupled nitrificationdenitrification $\left(D_{N}\right)$ and the remainder denitrification of nitrate diffusing from the water column $\left(\mathrm{D}_{\mathrm{W}}\right)$. (B) DNRA rates, the cross hatched area of the bar indicates DNRA activity coupled to sediment nitrification $\left(\mathrm{DNRA}_{\mathrm{N}}\right)$ and the remainder DNRA of nitrate diffusing from the water column $\left(\mathrm{DNRA}_{\mathrm{W}}\right)$. (C) Total nitrate reduction rates, the cross hatched area of the bar is total DNRA and the remainder denitrification

ranged between 180 and $240 \mu \mathrm{mol} \mathrm{N} \mathrm{m} \mathrm{N}^{-2} \mathrm{~h}^{-1}$ and were not significantly different between stations ( $p$ > 0.05), although the mean rate at Stn $M$ was approximately $30 \%$ higher than that at the other 2 stations. Considering the contributions of $D_{N}$ and $D_{W}$ to total denitrification, $\mathrm{D}_{\mathrm{W}}$ was the dominant component at all 3 stations in winter, accounting for 65 to $95 \%$ of total denitrification (Fig. 5A). The rate of $\mathrm{D}_{\mathrm{W}}$ at $\mathrm{Stn} \mathrm{M}$ was $230 \pm$ $39 \mu \mathrm{mol} \mathrm{m} \mathrm{m}^{-2} \mathrm{~h}^{-1}$, significantly higher $(\mathrm{p}<0.01)$ than the rates of 100 to $130 \mu \mathrm{mol} \mathrm{N} \mathrm{m}{ }^{-2} \mathrm{~h}^{-1}$ recorded at the other 2 stations. In contrast, rates of coupled nitrificationdenitrification were extremely low at Stn $M$ in winter and significantly different from $(\mathrm{p}<0.01)$ the $\mathrm{D}_{\mathrm{N}}$ rates of 50 to $60 \mu \mathrm{mol} \mathrm{m} \mathrm{m}^{-2} \mathrm{~h}^{-1}$ recorded at the control and clam farm stations.

In July, total denitrification rates were below $10 \mu \mathrm{mol}$ $\mathrm{N} \mathrm{m}^{-2} \mathrm{~h}^{-1}$ at Stns $\mathrm{C}$ and $\mathrm{M}$ and significantly different $(\mathrm{p}<0.01)$ from the rate of $74 \pm 3 \mu \mathrm{mol} \mathrm{m}{ }^{-2} \mathrm{~h}^{-1}$ measured at Stn V (Fig. 5A). Nitrification was an important source of nitrate for denitrification at Stns C and V, accounting for approximately 50 and $70 \%$, respectively, of total denitrification, with the rate at Stn V of $50 \pm 3 \mu \mathrm{mol} \mathrm{N} \mathrm{m}{ }^{-2} \mathrm{~h}^{-1}$ being significantly higher $(\mathrm{p}<$ 0.01 ) than that at the control site. Conversely, at Stn M, coupled nitrification-denitrification was completely absent in July. Due to the low water column nitrate concentration (Table 1), rates of $\mathrm{D}_{\mathrm{W}}$ were very much lower than those determined in winter at all 3 stations (Fig. 5A). Rates at Stns C and $M$ were 5 and $8 \mu \mathrm{mol} \mathrm{m}{ }^{-2}$ $\mathrm{h}^{-1}$, respectively, and significantly lower than the rate of $24 \mu \mathrm{mol} \mathrm{m}{ }^{-2} \mathrm{~h}^{-1}$ recorded at the clam farm Stn V.

Significant rates of DNRA were only recorded at Stn M (Fig. 5B), where rates of $85 \pm 11$ and $130 \pm$ $9 \mu \mathrm{mol} \mathrm{m} \mathrm{m}^{-2} \mathrm{~h}^{-1}$ were recorded in February and July, respectively. At this station, DNRA was fuelled almost exclusively by nitrate from the overlying water in both February and July, and during the summer sampling campaign, the input of ammonium to the sediment via DNRA was >15-fold higher than $\mathrm{N}$ losses via denitrification. At Stns C and V, DNRA was never a significant sink for nitrate, with measured rates falling within the range of 1 to $6 \mu \mathrm{mol} \mathrm{m} \mathrm{m}^{-2} \mathrm{~h}^{-1}$ during both sampling campaigns, representing only 2 and $10 \%$ of total nitrate reduction at these sediments (Fig. 5C).

The mussel ropes were also a site for denitrification at Stn M (Table 4). Total denitrification rates were approximately 5 and $10 \mu \mathrm{mol} \mathrm{N} \mathrm{kg}^{-1} \mathrm{~h}^{-1}$ in February and July, respectively. However, due to the large differences in the rope biomasses between the 2 periods, overall denitrification rates were higher on an areal basis in winter than summer (128 to 269 versus 24 to $36 \mu \mathrm{mol} \mathrm{m} \mathrm{m}^{-2} \mathrm{~h}^{-1}$ ). These denitrification rates were mainly fuelled by water column nitrate, although in summer significant rates of coupled nitrificationdenitrification were also measured and accounted for approximately $1 / 3$ of total denitrification. Although DNRA activity was detectable on the mussel ropes, data were equivocal due to high variability between replicates, and therefore biomass-specific and areal rates of this process were not calculated for the mussel ropes. 


\section{DISCUSSION}

\section{Density and biomass of the farmed organisms}

Density and biomass of Tapes philippinarum at Stn V were high in February and remained so in July even though the largest size classes of clams had been harvested between the 2 sampling dates. The clam densities of 1000 to 3000 ind. $\mathrm{m}^{-2}$ are high for the Sacca di Goro where cultivated densities of 100 to 500 ind. $\mathrm{m}^{-2}$ are more typical (Castaldelli et al. 2003, Viaroli et al. 2003), although similarly high densities have been reported for other intensively farmed areas of the lagoon (Bartoli et al. 2001). Lower densities of juvenile clams were also present at Stn C in July, probably as a result of natural recruitment or the drift of seed from the adjacent clam fields. Thus, as discussed in the following sections, this site cannot be considered as a true control in July. Similarly, the data collected at Stn M in the same summer sampling campaign are not typical of this site (Nizzoli 2003), as due to a sustained period of high temperatures and localised hypoxic and anoxic events in June, most of the mussels had either been harvested or had died prior to the July sampling. Thus, fluxes across the mussel ropes were reduced due to the low biomass of mussels present. Benthic metabolism and sediment-water column fluxes were also reduced as a result of the low rates of biodeposition in the preceding period, as mussel biodeposits cause only transitory stimulations in sediment organic matter turnover rates (Grenz et al. 1990).

\section{Sediment metabolism and ammonium fluxes}

Benthic metabolism, determined as SOD and $\mathrm{CO}_{2}$ production, and ammonium regeneration rates measured at all 3 stations, including the control site, were high in both seasons, reflecting the general eutrophic nature of the Sacca di Goro lagoon (Viaroli et al. 2001). Highest rates were recorded at the clam farm Stn V, confirming that Tapes philippinarum populations have a major influence on benthic metabolism and nutrient regeneration rates (Magni et al. 2000, Bartoli et al. 2001), as do other infaunal filter-feeding bivalves (Doering et al. 1987, Yamuro \& Koike 1994, Pelegrí \& Blackburn 1995). SOD was lower at the control and mussel farm stations in winter, although carbon oxidation rates were 2 -fold higher at the mussel farm, indicating that anaerobic respirations were more important at this station. Similarly, the ammonium efflux rate at the mussel farm site was 7 -fold greater than at the control site, reflecting the higher carbon oxidation rate and dominance of anaerobic metabolism. Anaerobes have lower carbon assimilation efficiencies than aerobes and consequently lower nitrogen requirements for growth (Stouthammer 1979, Goldman \& Dennet 1991). Therefore, anaerobic mineralization of organic matter proportionally generates more ammonium than aerobic mineralization of the same organic matter, as less of the carbon and nitrogen is assimilated into the bacterial biomass.

During the summer sampling, $\mathrm{SOD}$ and $\mathrm{CO}_{2}$ effluxes were similar at the mussel farm and control stations, and the ammonium efflux was only $60 \%$ higher at the mussel farm station. However, as discussed in the preceding section, this represents an atypical situation, as all 3 rates would be overestimated at the control site due to the presence of juvenile clams. These would have stimulated SOD, $\mathrm{CO}_{2}$ production and ammonium effluxes, which are directly proportional to clam biomasses (Bartoli et al. 2001). Conversely, the same rates at the mussel farm site would be greatly underestimated, as the atypically low mussel biomass means that the supply of 'fresh' labile organic matter as mussel biodeposits would have been much lower than normal.

To put the degree of these respective under and overestimates into perspective, on 1 August of the preceding year, $\mathrm{SOD}, \mathrm{CO}_{2}$ and ammonium effluxes determined at the control station in the absence of clams were $-2.5,2.4$ and $0.2 \mathrm{mmol} \mathrm{m}^{-2} \mathrm{~h}^{-1}$, respectively (Nizzoli 2003 ) or 61,33 and $35 \%$ respectively of the rates determined in this study. Whereas, at the mussel farm site at a more normal density of $19.3 \mathrm{~kg}$ wet weight $\mathrm{m}^{-2}$, $\mathrm{SOD}, \mathrm{CO}_{2}$ and ammonium effluxes were $-9.3,17.3$ and $1.6 \mathrm{mmol} \mathrm{m}^{-2} \mathrm{~h}^{-1}$ (Nizzoli 2003) or 194, 237 and $155 \%$, respectively, of the rates determined here.

Taking into account these more typical conditions, it would appear at first glance that clam and mussel farming have similar influences on oxygen and nutrient dynamics, as benthic fluxes of oxygen, $\mathrm{CO}_{2}$ and ammonium are stimulated to approximately the same degree by both types of farming. However, this simple comparison of benthic fluxes does not represent a true evaluation of the overall impacts of the 2 aquaculture types. The measurements at the clam farm site include both the direct effects of the clams' metabolic activities and their indirect effects on sediment metabolism through biodeposition of organic matter. However, the benthic fluxes at the mussel farm site include only the effects of biodeposition on sediment processes, as the mussels themselves are suspended in the water column. Oxygen and ammonium fluxes of -54 and $6.2 \mathrm{mmol} \mathrm{m}^{-2} \mathrm{~h}^{-1}$, respectively, across the mussel ropes in February were an order of magnitude higher than the benthic fluxes at either of the farmed stations and 30 - to 50-fold higher than those at the control site. Even at the low mussel biomasses present during July, the oxygen and ammonium fluxes across the mussel 
ropes were similar to the benthic fluxes, whereas those measured in August of the previous year, -48 and $5.2 \mathrm{mmol} \mathrm{m}^{-2} \mathrm{~h}^{-1}$ for oxygen and ammonium, respectively, (Nizzoli 2003) were an order of magnitude higher than the corresponding benthic fluxes determined in summer at each of the 3 sites in this study. A similar predominance of suspended oyster cultures over the sediment compartment in inorganic nitrogen regeneration in a French Mediterranean lagoon has also recently been reported (Mazouni 2004). These data emphasise the fact that in studies of the effects of suspended aquaculture systems, both the suspended cultures and the benthic compartment need to be monitored in tandem, an approach that is only rarely employed (Mazouni 2004).

Consequently, when oxygen and ammonium fluxes across the mussel rope are included, the overall impacts of mussel farming on local oxygen demand and nitrogen regeneration rates are considerably greater than those of clam farming. Even if one takes into account that in the $0.4 \mathrm{~km}^{2}$ area of the lagoon licensed for mussel farming, for each square meter occupied by mussel ropes there are approximately 15 to $20 \mathrm{~m}^{2}$ of open water. At normal mussel densities, the mean oxygen demand and ammonium regeneration rates of an average square meter of the mussel farm area would be approximately double those of a square meter of the clam farm station. However, even these simple calculations probably underestimate the relative difference between the 2 types of cultivation, as the clam densities of $2600 \pm 170$ and $1220 \pm 120$ ind. $\mathrm{m}^{-2}$ in February and July are in the upper range of densities farmed in the Sacca di Goro, and 100 to 500 ind. $\mathrm{m}^{-2}$ are more typical of the bulk of the farmed area (Bartoli et al. 2001, Castaldelli et al. 2003, Viaroli et al. 2003). Since SOD and ammonium fluxes in the farmed zones are directly proportional to clam biomass (Bartoli et al. 2001, Viaroli et al. 2003), the SODs and ammonium fluxes determined in this study may be more representative of the maximal, rather than typical impacts of clam farming. Therefore, the relative impacts of mussel farming on oxygen and ammonium fluxes are probably much greater than double those of most clam farm zones where densities are considerably lower than at our site. Thus, although in the Sacca di Goro lagoon the areas licensed for clam and mussel farming are 8 and $0.4 \mathrm{~km}^{2}$, respectively, the ratio of the contributions of the 2 farming types to the lagoonal oxygen and nitrogen budgets will be very much lower than this 20:1 ratio, and may even be similar.

Although it is obvious from the preceding discussion that bivalve farming in the Sacca di Goro has a major influence on the overall nutrient budgets of the lagoon, due to the high rates of nutrient recycling in the farmed areas and the high proportion of the lagoon surface which is cultivated, it is not possible to make meaningful quantitative estimates of these influences here. This results from the very limited temporal and spatial resolution of our data set and the large number of relevant variables, which are either unknown or poorly defined. For example, although the areas licensed for mussel and clam farming are known, the actual areas cultivated are not. Nor are the densities of organisms cultivated, although in the case of clams the few available data indicate that this varies at least 30 -fold (Bartoli et al. 2001, Castaldelli et al. 2003, Viaroli et al. 2003).

Whilst both types of bivalve farming stimulated overall benthic metabolism, the mode of this stimulation differed, as evidenced by the benthic respiratory quotients. The benthic respiratory quotient (BRQ) is the ratio between the rates of sediment dark $\mathrm{CO}_{2}$ production and SOD, which integrates aerobic respiration and the bacterial and chemical oxygen demand for the oxidation of reduced species generated by anaerobic metabolisms. At the mussel farm station the $\mathrm{BRQ}$ ranged between 1.8 and 2.0, whereas at the clam farm station, values were between 1.1 and 1.5, a similar range to that recorded at the control site (0.8 and 1.6). Theoretically, under balanced conditions, where all organic matter is either metabolised aerobically or any reduced products of anaerobic respiration are reoxidised, the BRQ value would be in the range of 0.7 to 1.1, depending upon the composition of the organic matter mineralised (Andersen \& Kristensen 1988). However, values substantially greater than unity indicate incomplete re-oxidation of the end products of anaerobic respirations, which consequently accumulate in the sediment. Thus, whilst mussel farming induced a strong shift in benthic metabolism towards anaerobic respirations and the accumulation of reduced metabolites in the sediment compared to the control site, the balance of benthic metabolism at the clam farm site remained very similar to that at the control site.

This conclusion is supported by studies of sediment pools of reduced sulphur compounds, which represent the accumulated end products of sulphate reduction, the dominant anaerobic metabolism in marine sediments (Jørgensen 1982), in the sediments of the same 3 sites. The sediments at the mussel farm station was jet black almost to the surface, and reduced sulphur pools in the upper $10 \mathrm{~cm}$ of sediment of 50 to $150 \mu \mathrm{mol} \mathrm{ml}^{-1}$ were 4 to 30 times higher, depending upon season, than those at the same sediment depths at the control station (D. T. Welsh unpubl. data). In contrast, sediment reduced sulphur pools at clam farm station were 3 to $17 \mu \mathrm{mol} \mathrm{ml}{ }^{-1}$ and similar to those at the control station in all seasons (D. T. Welsh unpubl. data). Thus, the indirect effect of mussel farming on the sediment 
through biodeposition of organic matter was stimulation of sediment reduction, as has been observed at other mussel farm sites (Dahlback \& Gunnarsson 1981, Grant et al. 1995, Gilbert et al. 1997). In contrast, the direct interaction of clams with the sediment largely negates the impact of biodeposition, as they also increase oxygen transfer to the sediment through bioturbation, the increased surface area offered for oxygen exchange by their burrow walls, diffusion of oxygen from their tissues and the infusion of the sediment with the overlying water induced by their filtration currents and/or physical movements (Pelegrí \& Blackburn 1995, Kristensen 2000, Berg et al. 2001, Welsh 2003, Welsh \& Castaldelli 2004). Therefore, although clam cultivation stimulates overall sediment metabolism through the biodeposition of organic matter, the parallel enhancement of oxygen transfer to the sediment by the clams promotes aerobic metabolisms and the reoxidation of reduced compounds, avoiding the reduction in sediment redox status that biodeposition alone induces at the mussel farm station.

\section{Impacts on nitrate fluxes and nitrate reduction rates}

In winter, high water column nitrate concentrations drove large fluxes to the sediment at all 3 sites. Whereas in summer, at low water column nitrate concentrations, significant fluxes to the sediment were only recorded at the mussel farm station. This nitrate flux indicates that the oxic-anoxic interface was extremely close to the sediment surface during this period, as diffusion rates are proportional to the square of the diffusion path length, as well as the solute concentration gradient. Therefore, as the nitrate concentration gradient must be small because of the low water column concentration, the diffusion path length to the nitrate reduction zone in the sediment (just below the oxic-anoxic interface; Christensen et al. 1989) must be short to allow the observed high nitrate flux.

As would be expected, sediment reduction rates of water column nitrate $\left(D_{W}+D_{N R A_{W}}\right)$, showed the same trends as nitrate fluxes, with high rates at all 3 sites in winter and highest rates at the mussel farm site in summer. However, the partitioning of nitrate between the competing nitrate reduction pathways differed considerably between the sites. At the control and clam farm stations, denitrification was the dominant sink for nitrate in both seasons and only 2 and 10, and 3 and $6 \%$ of the nitrate reduced at Stns C and V in winter and summer, respectively, was recycled to ammonium via DNRA. In contrast, 26 and $94 \%$ of nitrate was reduced to ammonium at the mussel farm site in winter and summer, respectively. This predominance of
DNRA over denitrification in the sediments below the mussel ropes is in accord with potential rate measurements for sediments below suspended oyster and mussel cultures (Gilbert et al. 1997, Christensen et al. 2003) and below cage fish farms (Kaspar et al. 1988, Christensen et al. 2000), and the general hypothesis that DNRA is favoured in organically enriched, highly metabolic sediments (Tiedje 1988).

DNRA can proceed via several metabolic pathways and occurs in a physiologically diverse range of facultative and obligate anaerobes, including both heterotrophs and chemoautotrophs (Keith et al. 1982 Mitchell et al. 1986, Dannenberg et al. 1992, Dalsgaard \& Bak 1994, Eisenmann et al. 1995), and therefore its regulation is likely to be complex. Several factors have been proposed to favour DNRA over denitrification, including high temperatures, high ratios of labile organic carbon to nitrate (electron donor:electron acceptor) and/or low nitrate availability, as reduction of nitrate to ammonium accommodates 8 electrons compared to the 5 consumed by denitrification and nitrate ammonifiers generally have a higher affinity for nitrate than denitrifiers (Tiedje et al. 1982, Jørgensen 1989, Dalsgaard \& Bak 1994, Childs et al. 2002), and reduced, especially sulphidic conditions in the sediment (Jensen \& Cox 1992, Brunet \& Garcia-Gil 1996, An \& Gardner 2002, Christensen et al. 2003). Recent studies have proposed that free sulphides play a critical role in the switch of nitrate reduction away from denitrification towards DNRA, through direct inhibition of denitrification and provision of an electron donor for DNRA (Brunet \& Garcia-Gil 1996, An \& Gardner 2002, Christensen et al. 2003). Our data are in general agreement with this hypothesis, as DNRA was the predominant pathway for nitrate reduction in summer and a substantial pathway in winter in the sulphide-rich mussel farm sediments. Conversely, in the sulphide-poor control and clam farm sediments, DNRA was never a significant sink for nitrate, although the inputs of labile organic matter as clam biodeposits and high metabolic activity at this site, especially in summer when combined with high temperature and low nitrate availability, would be expected to favour DNRA over denitrification. However, some caution must be exercised in concluding that sulphide is the determinant or only factor regulating the partition of nitrate between DNRA and denitrification. High sulphate reduction rates and reduced sulphur pools may simply be indicators of the population densities of sulphatereducing bacteria and the fermentative bacteria, which furnish sulphate reducers with substrates, as DNRA is a common trait amongst both of these groups (Keith et al. 1982, Mitchell et al. 1986, Dannenberg et al. 1992, Dalsgaard \& Bak 1994). Therefore, the correlation between sulphate reduction, reduced sediment 
sulphur pools and the relative dominance of DNRA may be coincidental, as the former 2 factors may simply reflect the population sizes of bacteria able to perform DNRA.

The 3 studied sites differed considerably in the sources of nitrate that fuelled nitrate reduction. Here we will limit the discussion of these sources to the dependence of denitrification on nitrate from the water column $\left(D_{\mathrm{W}}\right)$ and nitrate generated in the sediment by nitrification $\left(D_{N}\right)$. The relative dependence of DNRA on these sources is identical, since rates of DNRA coupled to nitrification $\left(\mathrm{DNRA}_{\mathrm{N}}\right)$ are calculated from the rate of $\mathrm{DNRA}_{\mathrm{W}}$ and the ratio between $\mathrm{D}_{\mathrm{W}}$ and $\mathrm{D}_{\mathrm{N}}$ (see 'Material and methods'). During winter when water column nitrate concentrations were high, denitrification at all 3 sites was fuelled principally by this source. However, whilst coupled nitrification-denitrification accounted for $\sim 30 \%$ of denitrification at the control and clam farm stations, nitrification supplied only $3 \%$ of denitrification at the mussel farm. In summer, the inter-station differences were even greater. At the mussel farm site, denitrification rates were extremely low, since, as discussed above, DNRA was the dominant nitrate-reducing process, but both denitrification and DNRA were fuelled exclusively by water column nitrate and $\mathrm{D}_{\mathrm{N}}$ was undetectable. At the control station, denitrification was higher and fuelled equally by the water column and nitrification. Whereas at the clam farm site, denitrification rates were 7 - to 10 -fold higher than at the other stations and coupled nitrificationdenitrification accounted for $\sim 70 \%$ of this activity.

These apparently opposite shifts, in the provision of nitrate for nitrate reduction processes at the shellfish farm sites compared to the control station can largely be explained by differences in the cultivation methods, which induce either biodeposition alone (mussels) or biodeposition and bioturbation (clams), as efficient nitrification depends upon an adequate supply of both ammonium and oxygen. Model and microcosm studies indicate that nitrification and coupled nitrificationdenitrification rates are highest at moderate organic matter loads, as at low loads nitrification is limited by ammonium availability and at high loads by competition for oxygen with aerobic heterotrophs and other chemoautotrophs (Blackburn \& Blackburn 1993a,b, Caffrey et al. 1993, Sloth et al. 1995, Blackburn 1996). Thus, at the mussel farm site, which receives very high inputs of organic matter, nitrification rates and consequently nitrate reduction coupled to nitrification would be expected to be low due to competition for oxygen. This intense competition is reflected by the high BRQ and reduced sulphur pools at this site, which demonstrate that carbon oxidation and production of reduced metabolites far outstrip the supply of oxygen to the sediment from the water column. Additionally, due to this imbalance in benthic metabolism, the inhibition of nitrification may be further reinforced by direct inhibition by toxic free sulphides (Kaspar et al. 1988, Joye \& Hollibaugh 1995). In contrast, although clams also biodeposit organic matter as faeces and pseudofaeces, and stimulate benthic metabolism to a similar degree, rates of coupled nitrification-denitrification in the clam farm sediment were similar in winter and almost 10-fold higher in summer than those at the control station. This apparent contradiction of the conclusions of the above-mentioned models and microcosm studies, that high organic matter loads inhibit coupled nitrification-denitrification, can be explained by the direct interaction of the clams with the sediment environment. In addition to inducing organic matter inputs to the sediment, the clams also augment the transfer of oxygen (Pelegrí \& Blackburn 1995, Welsh 2003, Welsh \& Castaldelli 2004), as discussed in the preceding section. Thus, clam farming increases the availability of both of the substrates for nitrification, by enhancing oxygen transfer to the sediment and ammonium regeneration rates through the biodeposition of organic matter.

The stimulation of nitrification and/or coupled nitrification-denitrification by burrow-forming macrofauna has been attributed to the colonisation of the burrow walls by nitrifying bacteria, which gain access to ammonium diffusing from the adjacent anoxic sediments, and oxygen from the water circulated within the burrow (Kristensen et al. 1985, Mayer et al. 1995). However, in the case of bivalves such as Tapes philippinarum, the animal's siphon lines its burrow and direct contact of the wall sediments with oxygenated water would only occur when the siphon is withdrawn during movement or in response to perceived threats. Therefore, the oxidized sediments around bivalve burrows may be due principally to the diffusion of oxygen from the animal's tissues (Pelegrí \& Blackburn 1995, Hansen et al. 1996). Whilst the significant potential nitrification rates in sediments around the siphons (Mayer et al. 1995) and associated with the siphons themselves and the external surfaces of the clams' shells (Welsh \& Castaldelli 2004) demonstrate that this mechanism of oxygen transfer is sufficient to support nitrifiers, it leads to problems in interpreting rates of coupled nitrification-denitrification determined using the isotope pairing technique.

The isotope pairing technique relies on homogenous mixing within the denitrification zone of the added ${ }^{15} \mathrm{~N}$-nitrate diffusing from the water column with the nitrate produced by nitrification in the sediment to allow calculation of coupled nitrification-denitrification from the ratio of ${ }^{29} \mathrm{~N}_{2}$ to ${ }^{30} \mathrm{~N}_{2}$ (Nielsen 1992). In the clam farm sediment, such uniform mixing may not be achieved, as although oxygen can diffuse across the 
animals' tissues to the sediment, diffusion of charged ions such as nitrate would be greatly impeded (Williams 1981). Thus, in the denitrification zones around the clams' burrows, there would be no homogenous mixing of the ${ }^{15} \mathrm{~N}$-nitrate tracer with the nitrate generated by in situ nitrification, as the tracer may only arrive intermittently to these zones when the animal withdraws its siphon. Such non-homogenous mixing would result in an underestimation of rates of coupled nitrification-denitrification (Nielsen 1992). Therefore, our $\mathrm{D}_{\mathrm{N}}$ data for the clam farm site should be considered as minimum estimates of coupled nitrification-denitrification.

In addition to benthic denitrification, denitrification was also detectable associated with the mussel ropes themselves at the mussel farm station. The water column was the dominant source of nitrate driving this denitrification, with $\mathrm{D}_{\mathrm{W}}$ accounting for 95 and $75 \%$ of total denitrification in winter and summer, respectively. However, the presence of even low rates of $D_{N}$ confirms potential rate measurements indicating that the mussel ropes are colonised by nitrifiers (Welsh \& Castaldelli 2004) as well as denitrifiers (Kaspar et al. 1985). Thus, the mussel ropes play a role in nitrogen cycling, not only through the physiological activities of the animal community, but also by providing oxic and anoxic niches for specific bacterial populations. Quantitatively, on a per square meter basis the denitrification rates on the mussel ropes were equivalent to 76 and $385 \%$ of those of the underlying sediment in winter and summer, respectively. However, considering that there are $\sim 15$ to $20 \mathrm{~m}^{2}$ of open water for each square meter covered by mussels in the farmed area, denitrification associated with the ropes would represent $\sim 5$ and 15 to $25 \%$ of overall denitrification in the farmed area in winter and summer respectively. However, at more typical summer densities the contribution of the ropes would increase to 70 to $80 \%$ of total denitrification, assuming that the activity rate per kilogram of rope culture was similar. But this increased relative contribution is mainly due to the very low sediment denitrification rates and would be of little quantitative significance to overall summer denitrification rates, which would still be several fold lower than those at the clam farm site.

\section{Impacts of nitrate reduction processes on sediment nitrogen budgets}

In terms of sediment nitrogen budgets, coupled nitrification-denitrification can be considered as the sediment capacity to dissipate internal nitrogen loads, whereas DNRA of nitrate from the water column represents an addition of new nitrogen to the sediment.
Therefore, the balance between these determines whether nitrate reduction processes result in an increase or decrease in sediment nitrogen loading. Considering this balance between $\mathrm{D}_{\mathrm{N}}$ and $\mathrm{DNRA}_{\mathrm{W}}$, nitrate reduction processes resulted in a net elimination of 57 and $48 \mu \mathrm{mol} \mathrm{N} \mathrm{m}^{-2} \mathrm{~h}^{-1}$ in winter at the control and clam farm stations respectively, compared to a net input of $73 \mu \mathrm{mol} \mathrm{N} \mathrm{m}^{-2} \mathrm{~h}^{-1}$ at the mussel farm station. In summer, the net loss at the control station was minimal $\left(5 \mu \mathrm{mol} \mathrm{N} \mathrm{m} \mathrm{N}^{-2} \mathrm{~h}^{-1}\right)$, whereas the stimulation of $\mathrm{D}_{\mathrm{N}}$ at the clam farm site sustained net nitrogen losses at a similar level to those recorded in winter $\left(48.7 \mu \mathrm{mol} \mathrm{N} \mathrm{m}^{-2} \mathrm{~h}^{-1}\right)$. In contrast, there was a net input of $129 \mu \mathrm{mol} \mathrm{N} \mathrm{m}{ }^{-2} \mathrm{~h}^{-1}$ to the sediment at the mussel farm site, due to the complete absence of $\mathrm{D}_{\mathrm{N}}$ and the dominance of $\mathrm{DNRA}_{\mathrm{W}}$ at this time. Thus, whilst nitrate reduction processes in the clam farm sediments somewhat favour nitrogen elimination compared to the control sediments, due to higher losses during summer, the same processes result in large inputs of nitrogen to the sediment in the mussel farm area.

\section{CONCLUSIONS}

Whilst both mussel and clam farming greatly stimulate local oxygen demand and nitrogen regeneration rates, our data indicate that despite the smaller area devoted to mussel farming, this may be the more environmentally damaging type of aquaculture in the Sacca di Goro lagoon since:

(1) The combined oxygen demand and nitrogen regeneration rates of the mussel ropes and underlying sediments are very much greater than those caused by clam farming.

(2) Biodeposition alone results in a preferential stimulation of anaerobic metabolism below the mussel ropes, resulting in sediment reduction and inhibition of processes such as nitrification and denitrification, whereas the combination of biodeposition and direct interaction of the clams with the sediment maintains balanced benthic metabolism.

(3) Although mussel farming somewhat stimulates denitrification of water column nitrate in winter, the larger stimulation of DNRA and inhibition of coupled nitrification-denitrification results in large net inputs of nitrogen to the sediments, whereas the effects of clam farming on the same processes result in moderate net losses of nitrogen from the sediments.

Acknowledgements. The authors are indebted to G. Castaldelli and S. Mantovani (University of Ferrara) for assistance with sampling, and E. Turolla of the Centre for Mollusc Research, Goro for the provision of laboratory facilities and information on aquaculture practises in the Sacca di Goro. This research was supported by the Italian Ministry for Uni- 
versity, Scientific and Technological Research (COFIN 2000, I. Ferrari) and the Australian Research Council (grant DP0559935).

\section{LITERATURE CITED}

An S, Gardner WS (2002) Dissimilatory nitrate reduction to ammonium (DNRA) as a nitrogen link, versus denitrification as a sink in a shallow estuary (Laguna Madre/Baffin Bay, Texas). Mar Ecol Prog Ser 237:41-50

Andersen FO, Kristensen E (1988) The influence of macrofauna on estuarine benthic community metabolism: a microcosm study. Mar Biol 99:591-603

Anderson LG, Hall POJ, Iverfeldt A, Van Der Loeff MMR, Sundby B, Westerlund SFG (1986) Benthic respiration measured by total carbonate production. Limnol Oceanogr 31:319-329

APHA (American Public Health Association) (1975). Standard methods for the examination of water and wastewaters, 14th edn. APHA, Washington, DC

Bartoli M, Nizzoli D, Viaroli P, Turolla E, Castaldelli G, Fano EA, Rossi R (2001) Impact of Tapes philippinarum farming on nutrient dynamics and benthic respiration in the Sacca di Goro. Hydrobiologia 455:202-212

Baudinet D, Alliot E, Berland B, Grenz C, Plante-Cuny MR, Plante R, Salen-Picard C (1990) Incidence of mussel culture on biogeochemical fluxes at the sediment-water interface. Hydrobiogia 207:187-196

Berg P, Rysgaard S, Funch P, Sejr MK (2001) Effects of bioturbation on solids and solutes in marine sediments. Aquat Microb Ecol 26:81-94

Blackburn TH (1996) Nitrogen gas flux from sediments: insights from simulation modelling. Aquat Microb Ecol 10: 209-211

Blackburn TH, Blackburn ND (1993a) Rates of microbial processes in sediments. Phil Trans R Soc Lond A 344:49-58

Blackburn TH, Blackburn ND (1993b) Coupling of cycles and global significance of sediment diagenesis. Mar Geol 113: 101-110

Bonin P, Omnes P, Chalamet A (1998) Simultaneous occurrence of denitrification and nitrate ammonification in sediments of the French Mediterranean Coast. Hydrobiologia 389:169-182

Bower CE, Holm Hansen T (1980) A salicylate-hypochlorite method for determining ammonia in seawater. Can J Fish Aquat Sci 37:794-798

Brunet RC, Garcia-Gil LJ (1996) Sulfide-induced dissimilatory nitrate reduction to ammonia in anaerobic freshwater sediments. FEMS Microbiol Ecol 21:131-138

Caffrey JM, Sloth NP, Kaspar HF, Blackburn TH (1993) Effect of organic loading on nitrification and denitrification in a marine sediment microcosm. FEMS Microbiol Ecol 12: 159-167

Castaldelli G, Mantovani S, Welsh DT, Rossi R, Mistri M, Fano EA (2003) Impact of commercial clam harvesting on water column and sediment physicochemical characteristics and macrobenthic community structure in a lagoon (Sacca di Goro) of the Po River Delta. Chem Ecol 2/3:161-171

Childs CR, Rabalais NN, Turner RE, Proctor LM (2002) Sediment denitrification in the Gulf of Mexico zone of hypoxia. Mar Ecol Prog Ser 240:285-290

Christensen PB, Nielsen LP, Revsbech NP, Sørensen J (1989) Microzonation of denitrification activity in stream sediments as studied with a combined oxygen nitrous oxide sensor. Appl Environ Microbiol 55:1234-1241

Christensen PB, Rysgaard S, Sloth NP, Dalsgaard T,
Schwaeter S (2000) Sediment mineralization, nutrient fluxes, denitrification and dissimilatory nitrate reduction to ammonium in an estuarine fjord with sea cage trout farms. Aquat Microb Ecol 21:73-84

Christensen PB, Glud RN, Dalsgaard T, Gillespie P. (2003) Impacts of long line mussel farming on oxygen and nitrogen dynamics and biological communities of coastal sediments. Aquaculture 218:567-588

Dahlback B, Gunnarsson LAH (1981) Sedimentation and sulfate reduction under a mussel culture. Mar Biol 63: 269-275

Dalsgaard T, Bak F (1994) Nitrate reduction in a sulfatereducing bacterium, Desulfovibrio desulfiricans, isolated from rice paddy soil: sulfide inhibition, kinetics and regulation. Appl Environ Microbiol 60:291-297

Dannenberg S, Kroder M, Dilling W, Cypionka H (1992) Oxidation of $\mathrm{H}_{2}$, organic compounds and inorganic sulfur compounds coupled to reduction of $\mathrm{O}_{2}$ or nitrate by sulfate-reducing bacteria. Arch Microbiol 158:93-99

Doering PH, Kelly JR, Oviatt CA, Sowers T (1987). Effect of the hard clam Mercenaria mercenaria on benthic fluxes of inorganic nutrients. Mar Biol 94:377-383

Eisenmann E, Beuerie J, Sulger K, Kroneck PMH, Schumacher W (1995) Lithotrophic growth of Sulforosprillum delianum with sulfide as electron donor coupled to respiratory reduction of nitrate to ammonia. Arch Microbiol 164:180-185

FAO (Food and Agriculture Organization of the United States) (2003) The state of world fisheries and aquaculture 2002. Food and Agriculture Organization of the United States, Rome

Gilbert F, Souchu P, Bianchi M Bonin P (1997) Influence of shellfish farming activities on nitrification, nitrate reduction to ammonium and denitrification at the watersediment interface of the Thau lagoon, France. Mar Ecol Prog Ser 151:143-153

Goldman JC, Dennett MR (1991) Ammonium regeneration and carbon utilization by marine bacteria grown on mixed substrates. Mar Biol 109:369-378

Graf G, Rosenberg R (1997) Bioresuspension and biodeposition: a review. J Mar Systs 11:269-27

Grant J, Hatcher A, Scott DB, Pocklington P, Schaffer CT, Winters GV (1995) A multidisciplinary approach to evaluating impacts of shellfish aquaculture on benthic communities. Estuaries 18:124-144

Grenz C, Hermin MN, Baudinet D, Daumas R (1990) In situ biochemical and bacterial variation of sediments enriched with mussel biodeposits. Hydrobiologia 207:153-160

Hansen K, King GM, Kristensen E (1996) Impact of the softshell clam Mya arenaria on sulfate reduction in an intertidal sediment. Aquat Microb Ecol 10:181-194

Jensen KM, Cox RP (1992) Effects of sulfide and low redox potential on the inhibition of nitrous oxide reduction by acetylene in Pseudomonas nautical. FEMS Microbiol Lett 96:13-18

Jørgensen BB (1982) Mineralization of organic matter in the sea bed-the role of sulfate reduction. Nature 296: 643-645

Jørgensen KS (1989) Annual pattern of denitrification and nitrate ammonification in estuarine sediment. Appl Environ Microbiol 55:1841-1847

Joye SB, Hollibaugh JT (1995) Influence of sulphide inhibition of nitrification on nitrogen regeneration in sediments. Science 270:623-625

Kaiser MJ, Laing I, Utting SD, Burnell GM (1998) Environmental impacts of bivalve mariculture. J Shelf Res 17: $59-66$ 
Kaspar HF, Gillespie PA, Boyer IC, MacKenzie AL (1985) Effect of mussel aquaculture on the nitrogen cycle and benthic communities in Knepuru Sound, Marlborough Sounds, New Zealand. Mar Biol 85:127-136

Kaspar HF, Hall GH, Holland AJ (1988) Effects of sea cage salmon farming on sediment nitrification and dissimilatory nitrate reduction. Aquaculture 70:333-344

Keith SM, Macfarlane GT, Herbert RA (1982) Dissimilatory nitrate reduction by a strain of Clostridium butyricum isolated from estuarine sediments. Arch Microbiol 132:62-66

Knowles R (1990) Acetylene inhibition technique: development, advantages and potential problems. In: Revsbech NP, Sørensen J (eds) Denitrification in soil and sediment. Plenum Publishing Corporation, New York, p 151-166

Kristensen E. (2000) Organic matter diagenesis at the oxic/anoxic interface in coastal marine sediments, with emphasis on the role of burrowing animals. Hydrobiologia 426:1-24

Kristensen E, Jensen MH, Andersen TK (1985) The impact of polychaete (Nereis virens Sars) burrows on nitrification and nitrate reduction in estuarine sediments. J Exp Mar Biol Ecol 85:75-91

Magni P, Montani S, Takada C, Tsutsumi H (2000) Temporal scaling and relevance of bivalve nutrient excretion on a tidal flat of the Seto Sea, Japan. Mar Ecol Prog Ser 198: 139-155

Mayer MS, Schaffner L, Kemp WM (1995) Nitrification potential of benthic macrofaunal tubes and burrow walls: effects of sediment $\mathrm{NH}_{4}{ }^{+}$and animal irrigation. Mar Ecol Prog Ser 121:157-169

Mazouni N (2004) Influence of suspended oyster cultures on nitrogen regeneration in a coastal lagoon (Thau, France). Mar Ecol Prog Ser 276:103-113

Mazouni N, Gaertner JC, Deslous-Paoli JM, Landrein S, Geringer d'Oedenberg M (1996) Nutrient and oxygen exchanges at the water-sediment interface in a shellfish farming lagoon (Thau, France). J Exp Mar Biol Ecol 203: 92-113

Mitchell GJ, Jones JG, Cole JA (1986) Distribution and regulation of nitrate and nitrite reduction by Desulfovibrio and Desulfatomaculum species. Arch Microbiol 144:35-40

Naylor RL, Goldburg RJ, Primavera JH, Kautsky N and 6 others (2000) Effect of aquaculture on world fish supplies. Nature 405:1017-1024

Nielsen LP (1992) Denitrification in sediment determined from nitrogen isotope pairing. FEMS Microbiol Ecol 86: 357-362

Nizzoli D (2003) Regolazione dei processi biogeochimica in ambiente marini costieri con elevate densitá della fauna bentonica. PhD thesis, University of Parma

Pelegrí SP, Blackburn TH (1995) Effect of bioturbation by Neries sp., Mya arenaria and Cerastoderma sp. on nitrification and denitrification in estuarine sediments. Ophelia 42:289-299

Risgaard-Petersen N, Rysgaard S (1995) Nitrate reduction in sediments and waterlogged soil measured by ${ }^{15} \mathrm{~N}$ techniques. In: Alef K, Nannipieri P (eds) Methods in applied soil microbiology. Academic Press, London, p 287-310

Risgaard-Petersen N, Rysgaard S, Revsbech N (1995) Combined microdiffusion-hypobromite oxidation method for

Editorial responsibility: Otto Kinne (Editor-in-Chief), Oldendorf/Luhe, Germany determining nitrogen-15 isotope in ammonium. Soil Sci Soc Am J 59:1077-1080

Sfriso A, Pavoni B, Marcomini A, Orio AA (1992) Macroalgae, nutrient cycles and pollutants in the lagoon of Venice. Estuaries 15:517-528

Sloth NP, Blackburn TH, Hansen LS, Risgaard-Petersen N, Lomstein BA (1995) Nitrogen cycling in sediments with different organic loading. Mar Ecol Prog Ser 116:163-170

Sokal RR, Rohlf FJ (1995) Biometry. W.H. Freeman and Company, New York

Stouthammer AH (1979) The search for correlation between theoretical and experimental growth yields. Int Rev Biochem 21:1-47

Tiedje JM (1988) Ecology of denitrification and dissimilatory nitrate reduction to ammonium. In: Zehender AJB (ed) Biology of anaerobic microorganisms. Wiley, New York, p 179-244

Tiedje JM, Sexstone AJ, Myrold DD, Robinson JA (1982) Denitrification: ecological niches, competition and survival. Antonie van Leeuwenhoek J Microbiol 48:569-583

Viaroli P, Azzoni R, Bartoli M, Giordani G, Tajé L (2001) Evolution of the trophic conditions and dystrophic outbreaks in the Sacca di Goro lagoon (Northern Adriatic Sea). In: Faranda EM, Guglielmo L, Spezie G (eds) Mediterranean ecosystems: structures and processes. Springer-Verlag Italia, Milano, p 467-475

Viaroli P, Bartoli M, Giordani G, Azzoni R, Nizzoli D (2003) Short term changes of benthic fluxes during clam harvesting in a lagoon (Sacca di Goro, Po river Delta). Chem Ecol 19:189-206

Vollenweider RA, Rinaldi A, Montanari G. (1992) Eutrophication, structure and dynamics of a marine coastal system: results of a ten year monitoring along the Emilia-Romagna coast (Northwest Adriatic Sea). In: Vollenweider RA, Marchetti R, Viviani R (eds) Marine coastal eutophication. Elsevier, Amsterdam, p 63-106

Welsh DT (2003) It's a dirty job but someone has to do it: The role of marine benthic macrofauna in organic matter turnover and nutrient recycling to the water column. Chem Ecol 19:321-342

Welsh DT, Castaldelli G (2004) Bacterial nitrification activity directly associated with isolated benthic marine animals. Mar Biol 144:1029-1037

Welsh DT, Bartoli M, Nizzoli D, Castaldelli G, Riou SA, Viaroli P (2000) Denitrification, nitrogen fixation, community primary productivity and inorganic-N and oxygen fluxes in an intertidal Zostera noltii meadow. Mar Ecol Prog Ser 208:51-65

Welsh DT, Castaldelli G, Bartoli M, Poli D, de Wit R, Careri M, Viaroli P (2001). Denitrification in an intertidal seagrass meadow, a comparison of ${ }^{15} \mathrm{~N}$-isotope and acetylene block techniques; Dissimilatory nitrate reduction to ammonium as a source of $\mathrm{N}_{2} \mathrm{O}$. Mar Biol 139:1029-1036

Williams RJP (1981) Physico-chemical aspects of inorganic element transfer through membranes. Phil Trans R Soc Lond B 294:57-74

Yamuro M, Koike I (1994) Diel changes of nitrogen species in surface and overlying water of an estuarine lake in summer: evidence for benthic-pelagic coupling. Limnol Oceanogr 39:1726-1733

Submitted: November 11, 2004; Accepted: November 28, 2005 Proofs received from author(s): May 30, 2006 